\title{
Blood Donors on Medication - an Approach to Minimize Drug Burden for Recipients of Blood Products and to Limit Deferral of Donors
}

\author{
Christian D.K. Becker $^{\mathrm{a}}$ Dirk O. Stichtenoth ${ }^{\mathrm{b}} \quad$ Michael G. Wichmann $^{\mathrm{c}}$ Christof Schaefer $^{\mathrm{d}}$ \\ Ladislaus Szinicz ${ }^{\text {a }}$ \\ ${ }^{a}$ Institut für Pharmakologie und Toxikologie der Bundeswehr, München, \\ ${ }^{b}$ Institut für Klinische Pharmakologie, Medizinische Hochschule Hannover, \\ ${ }^{\mathrm{c}}$ Blutspendedienst des Bayerischen Roten Kreuzes, München, \\ ${ }^{\mathrm{d}}$ Pharmakovigilanz- und Beratungszentrum für Embryonaltoxikologie, Berliner Betrieb für zentrale gesundheitliche Aufgaben, Berlin, \\ Germany
}

\section{Key Words}

Blood donation · Donor deferral · Drug therapy .

Pharmacokinetics · Pharmacology

\section{Summary}

Background: Blood products derived from donors on medication can contain drugs which might pose a risk for the recipients or influence the quality of the product itself. Material and Methods: To judge the eligibility of blood donors on medication, 4 drug classes have been formed with respect to their pharmacological properties, and blood products have been divided in accordance with their single-donor plasma contents. Results: For drugs with dose-dependent pharmacodynamics, no deferral periods are necessary for donation of blood products containing less than $50 \mathrm{ml}$ single-donor plasma for application to adults. Waiting periods of $t_{\max }+$ $5 t_{1 / 2}$ were calculated for the other blood products. Teratogenic drugs do not require special considerations (exception: retinoids, thalidomide and lenalidomide, dutasteride or finasteride with waiting periods for all blood products). A deferral period of $t_{\max }+24 t_{1 / 2}$ is proposed for every blood product from blood donors on genotoxic drugs. Drugs without systemic effects can be neglected. Irreversible inhibitors of platelet function cause a 10-day waiting period if production of platelet concentrates is intended. Conclusion: Donors on medication are allowed to donate blood for blood products containing less than $50 \mathrm{ml}$ plasma of a single donor, like red blood cell concentrates, for the use in adults without deferral periods, except those taking retinoids, thalidomide, lenalidomide, dutasteride, finasteride, or genotoxic drugs.

\section{Schlüsselwörter \\ Blutspende · Spenderrückstellung · Medikamenten- einnahme $\cdot$ Pharmakokinetik · Pharmakologie}

\section{Zusammenfassung}

Hintergrund: Blutprodukte - gewonnen von Spendern unter Medikamenteneinnahme - können Arzneistoffe enthalten und dadurch ein Risiko für den Empfänger oder die Qualität des Blutproduktes bedeuten. Material und Methoden: Ein detailliertes Konzept zur Beurteilung von Blutspendern unter Medikamenteneinnahme wurde entwickelt. Die Arzneistoffe wurden nach pharmakologischen Gesichtspunkten in 4 Klassen und die Blutprodukte in solche, die mehr oder weniger als $50 \mathrm{ml}$ Einzelspenderplasma enthalten, eingeteilt. Ergebnisse: Sperrfristen sind nicht nötig, wenn der Spender Arzneistoffe mit einer dosisabhängigen Pharmakodynamik einnimmt und die Spende zur Gewinnung von Blutprodukten mit weniger als $50 \mathrm{ml}$ Einzelspenderplasma zur Anwendung am Erwachsenen gedacht ist. Für andere Blutprodukte wurden Sperrfristen von $t_{\max }+5 t_{1 / 2}$ berechnet. Teratogene Arzneistoffe bedürfen keiner gesonderten Berücksichtigung (Ausnahme: Retinoide, Thalidomid, Lenalidomid, Dutasterid und Finasterid mit Sperrfristen für alle Blutprodukte). Einnahme genotoxischer Substanzen erfordert eine Sperrfrist von $t_{\max }+24 t_{1 / 2}$ für alle Blutprodukte. Arzneimittel ohne systemischen Effekt können vernachlässigt werden. Nach Einnahme irreversibel wirkender Thrombozytenaggregationshemmer ist eine zehntägige Wartezeit erforderlich, wenn Thrombozytenkonzentrate gewonnen werden sollen. Schlussfolgerungen: Blutspender, die Medikamente einnehmen, können ohne Sperrfristen Blut zur Bereitung von Blutprodukten mit $<50 \mathrm{ml}$ Einzelspenderplasmaanteil (z.B. Erythrozytenkonzentrate) zur Anwendung bei Erwachsenen spenden (Ausnahme: Retinoide, Thalidomid, Lenalidomid, Dutasterid, Finasterid und genotoxische Substanzen).

\begin{tabular}{ll}
\hline KARGER & @ 2009 S. Karger GmbH, Freiburg \\
Fax +4976145207 14 & Accessible online at: \\
Information@Karger.de & www.karger.com/tmh \\
www.karger.com &
\end{tabular}




\section{Introduction}

Drugs with a potential to either reduce the quality of the blood product or to cause adverse effects in the recipient have been found in the blood of donors on medication [1-6]. The issue of blood donors on medication was not addressed systematically until the landmark paper of Ferner et al. in 1989 [7]. More than 10 years later, their concept was further specified and adapted to developments in blood banking procedures by Stichtenoth et al. [8]. Recent European guidelines on blood donation require deferral periods for blood donors on medication, taking into account the underlying disease, as well as pharmacodynamic and pharmacokinetic properties of the drug(s) $[9,10]$. However, at present no detailed transformation of guideline requirements into instructions for donor assessment can be found in the literature. To our knowledge, most of the blood banks do not defer donors for their medication, except after the use of teratogenic and platelet aggregation-inhibiting drugs [11-14]. If detailed deferral periods are defined at all, they often are not based on the pharmacokinetics of the specific drug [15]. To increase the safety of blood products as requested by official guidelines and to minimize the exclusion of donors because of medication, it is necessary to develop a concept for the assessment of donors. We propose deferral periods based on the pharmacodynamic and pharmacokinetic properties of the drug as well as on the plasma content of the blood product and its dilution upon transfusion, i.e. considering the concentration the drug will reach in the plasma of the recipient. In addition, modern blood banking procedures, quality management, and developments in transfusion medicine must be taken into account. Moreover, the concept should be easily applicable at the donation site. In our article, we do not address chronic diseases or malignancies as a risk factor for the donor him/herself or the recipient of the blood product.

\section{Material and Methods}

\section{Classification of Determinants}

Factors determining admission or deferral of blood donors on medication are i) pharmacological properties of the drug, ii) concentration of the drug in the donor's plasma, and iii) type and uses of the blood product the donation is intended for.

\section{Pharmacological Properties of Drugs}

Drugs differ widely by structure, and pharmacokinetic and pharmacodynamic properties. However, for the purpose of blood donor eligibility, they can be classified as follows:

Class 1: Drugs requiring consideration because of dose-dependent effects, including drugs with teratogenic, embryo- or fetotoxic potential (e.g. retinoids, thalidomide, valproic acid, vitamin $\mathrm{K}$ antagonists).

Class 2: Drugs requiring special consideration because of risks for the recipient due to a non-threshold-related genotoxic mechanism to harm (e.g. some antineoplastic drugs).

Class 3: Drugs requiring no consideration because they lack systemic effects, have little pharmacodynamic potency or a very high therapeutic index (e.g. some herbal products), or agents for replacement of physiological metabolites (e.g. thyroid hormones, nutrients, vitamins).

Class 4: Drugs influencing the quality of blood products; this class presently includes inhibitors of platelet function (e.g. acetylsalicylic acid) only.

\section{Concentration of Drugs in the Donor's Plasma}

Drug concentration in donor plasma at the time of donation depends on the time of intake, dose, route of application, drug preparation, and pharmacokinetic characteristics. The time interval between drug intake and maximum plasma concentration $\left(t_{\max }\right)$ as well as the plasma elimination half-life $\left(t_{1 / 2}\right)$ are crucial. $T_{\max }$ depends on drug release and absorption, whereas $t_{1 / 2}$ is influenced by distribution, metabolism, and excretion. These parameters are drug-specific (absorption, distribution, metabolism, excretion) or preparation-specific (release). If pharmacologically active metabolites are formed, they have to be taken into consideration. Unbound drug molecules are directly available for interaction with target structures and may cause pharmacological effects in the recipient [16-18]. However, the protein-bound fraction has to be taken into account as a drug reservoir because drug binding is reversible and dynamic.

\section{Blood Products}

Whole blood is usually fractionated after donation, e.g. plasma is removed to prepare erythrocyte concentrates or sometimes platelets are prepared. Depending on the blood component(s) it is associated with, a drug can be enriched or depleted in the resulting products. In general, the transfusion process leads to dilution of the blood product and the drug(s) it may contain. The post-transfusion concentration of such drugs will depend on the initial concentration in the blood product, i.e. mainly on the proportion of plasma derived from a single exposed donor, and on the transfused amount relative to the plasma volume of the recipient. Different types of blood products contain different amounts of plasma from a single donor due to the way of preparation. For practical reasons, blood products can be classified as: i) blood products containing up to $50 \mathrm{ml} / \mathrm{U}$ single-donor plasma, e.g. red blood cell concentrates (RBCC), pooled plasma (PP); ii) blood products containing more than $50 \mathrm{ml} / \mathrm{U}$ single-donor plasma, e.g. whole blood (WB), fresh-frozen plasma (FFP), platelet concentrates (PC) unless suspended in additive solution, whether prepared from pooled buffy coats or by apheresis.

\section{Basis for Calculating Deferral Periods}

\section{Class 1 Drugs}

After a period of $t_{\max }$ plus 5 plasma elimination half-lives following intake of a therapeutic dosage, approximately $97 \%$ of the drug are eliminated and the remaining plasma drug concentration is about $3 \%$ of the therapeutic drug concentration only. Therefore, the elimination then is estimated to be completed and no more dose-dependent clinical effects are to be expected [19]. Thus, $3 \%$ of a therapeutic drug concentration in the recipient's plasma after transfusion can be considered to be safe. Donor-derived drug concentration in the recipient's plasma after blood transfusion is mainly influenced by drug concentration in the donor's plasma at the time of donation and by component dilution in the recipient's organism.

\section{Blood Products Containing $50 \mathrm{ml}$ Single-Donor Plasma}

\section{Adults}

Plasma volume of normal adults is between about 39 and $44 \mathrm{ml} / \mathrm{kg}$ body weight $[20,21]$. We defined $2,500 \mathrm{ml}$ as an average plasma volume for a standard adult. When administering a blood product containing up to 50 $\mathrm{ml}$ single-donor plasma to a standard adult, the donor plasma is diluted about 50-fold. Assuming that the donation had been given at the time of $\mathrm{t}_{\max }$, the recipient's drug level should be close to $2 \%$ which is below the $3 \%$ safety threshold. This threshold is kept if recipients' plasma volumes are above $1,670 \mathrm{ml}$. 
Neonates and Children $<12$ Years

The plasma volume of 12-year-old children is normally $>1,670 \mathrm{ml}$ (average bodyweight of about $44 \mathrm{~kg}$ and plasma volume about $41-46 \mathrm{ml} / \mathrm{kg}$ ), therefore dilution is sufficient $[22,23]$. Administering a blood product containing up to $50 \mathrm{ml}$ single-donor plasma to a newborn or a child $<12$ years leads to a lower net dilution. Therefore, additional measures are required. A deferral interval of $t_{\max }+5 t_{1 / 2}$ after drug intake until blood donation causes a reduction of drug levels to $3 \%$ of the therapeutic concentration in the donor's plasma. Based on pharmacologic considerations, this concentration is regarded as safe without any dilution. That is why we suggest a special group of blood products intended for children $<12$ years (children RBCC) with deferral periods of $t_{\max }+5 t_{1 / 2}$.

\section{Blood Products Containing $>50 \mathrm{ml}$ Single-Donor Plasma}

When transfusing a blood product containing more than $50 \mathrm{ml}$ of singledonor plasma (average approximately $250 \mathrm{ml}$ ) to an adult, the dilution is only 10 -fold and would result in plasma drug levels of about $10 \%$ of the therapeutic concentration in the recipient. In this case, a deferral period for blood donation is necessary in order to achieve the $3 \%$ threshold. Therefore, deferral intervals of $t_{\max }+5 t_{1 / 2}$ guarantee that blood products containing more than $50 \mathrm{ml}$ single-donor plasma can be safely administered to both newborns/children $(<12$ years $)$ and adults.

\section{Teratogenic, Fetotoxic, or Embryotoxic Drugs}

Teratogenic, fetotoxic, or embryotoxic substances act in a dose-dependent fashion. As far as is known, teratogenic effects require effective minimum (peak) concentrations during the organ- and drug-specific teratogenic 'time window'. For ethical reasons, threshold concentrations of prenatal toxicity have not been investigated in clinical studies. However, there is convincing evidence by published case reports and case series with known teratogens that $3 \%$ of the therapeutic level of a teratogenic drug does not cause birth defects. This can be concluded from observations of unplanned pregnancies where a teratogenic drug treatment was withdrawn only a few half-lives before conception, e.g. with isotretinoin, thalidomide, or vitamin $\mathrm{K}$ antagonists [24-26].

Furthermore, requirements of drug manufacturers who normally tend to overestimate the teratogenic risk in their package leaflets to prevent any litigation indicate that a drug concentration of $3 \%$, resulting from plasma dilution or a deferral period of $t_{\max }+5 t_{1 / 2}$, is safe for the unborn child. For isotretinoin, apart from thalidomide one of the most potent teratogenic drugs in humans, a period of 1 month after termination of treatment until blood donation is required according to the manufacturer [27]. The longest elimination half-life reported is $167 \mathrm{~h}$ [28]. Thus, the required deferral period of 30 days is less than $t_{\max }+5 t_{1 / 2}$, and the resulting drug level may be higher than $3 \%$. For acitretin, the manufacturer stipulates a 1-year deferral interval prior to blood donation, which is about 3 half-lives of its highly teratogenic metabolite etretinate (about 120 days) [29, 30].

Animal experiments with dutasteride and finasteride indicated that testosterone-5-alpha-reductase inhibitors may have the potential to cause genital abnormalities in male fetuses but there is no evidence so far that this means a risk for humans too [31-33]. According to the American Association of Blood Banks' (AABB) medication deferral list, the U.S. Food and Drug Administration (FDA) recommends a deferral period of 6 months for dutasteride. This correlates with the deferral period of 25 weeks calculated by $\mathrm{t}_{\max }(1-3 \mathrm{~h})$ plus $5 \mathrm{t}_{1 / 2}(3-5$ weeks) $[13,32,34]$. For finasteride, the FDA and AABB recommend a 1-month deferral. $\mathrm{T}_{\max }$ is $2 \mathrm{~h}$ and $\mathrm{t}_{1 / 2} 3-14 \mathrm{~h}$ resulting in a 3 -day deferral calculated by $t_{\max }+5 \mathrm{t}_{1 / 2}$. The mean steady-state blood level is $9.2 \mathrm{ng} / \mathrm{ml}$ after $1 \mathrm{mg}$, and after an oral dose of $5 \mathrm{mg}$ a peak plasma concentration of $38.1 \mathrm{ng} / \mathrm{ml}$ is reported. [35-37]. Levels decrease to about $0.3 \mathrm{ng} / \mathrm{ml}$ (for $1 \mathrm{mg}$ dose) and about $1.2 \mathrm{ng} / \mathrm{ml}$ (for a $5-\mathrm{mg}$ dose) within 3 days $\left(t_{\max }+5 t_{1 / 2}\right)$. Transfusion of $250 \mathrm{ml}$ plasma containing $1.2 \mathrm{ng} /$ $\mathrm{ml}$ finasteride would supply about $300 \mathrm{ng}$ finasteride in total. As indicated by data from a toxicological study on monkeys and the fact that $5 \mu \mathrm{g}$ is the minimum dose to reduce dihydrotestosterone levels in man, a 3-day medication-free interval should be safe $[13,31,33,35,36]$.
In conclusion, transfusion of blood products contaminated with teratogenic, fetotoxic, or embryotoxic substances to pregnant women is safe for the unborn child if the final concentration in the mother's plasma is $3 \%$ or less of the therapeutic concentration. This can be guaranteed by dilution of plasma in the recipient or by applying donor deferral intervals of $t_{\max }+5 t_{1 / 2}$. For the most potent human teratogens - the retinoids, thalidomide, and its analogue lenalidomide $\left(\mathrm{t}_{1 / 2}<10 \mathrm{~h}\right)-\mathrm{at} \mathrm{t}_{\max }+5 \mathrm{t}_{1 / 2}$ deferral interval should be applied in any case to expand the safety margin. If, as for retinoids, a donor deferral period is required in the drug's product information, the deferral times for all blood products should follow these guidelines. Respecting the authority of the FDA, we apply deferral periods for all blood products also for dutasteride and finasteride as given in the FDA guideline, although there is no evidence that these drugs cause birth defects in humans, especially not in concentrations up to $3 \%$.

\section{Class 2 Drugs}

Substances that have been found to be genotoxic in humans usually are excluded from registration as a drug. Exceptions are only made for drugs for severe indications like cancer. In principle, threshold levels for genotoxicity cannot be defined because even a single molecule that reaches the DNA might have an effect. Therefore, not dilution factors after transfusion but the total dose of the genotoxic substance are relevant in this case. For the assessment of genotoxic impurities in active substances, the European Medicines Agency (EMEA) released the 'Guideline on the Limits of Genotoxic Impurities'. If a no-effect level cannot be defined, genotoxic substances should be avoided or exposure to them be minimized. If reduction is not possible, up to $1.5 \mu \mathrm{g}$ /day of a genotoxic substance is considered to be safe because of the resulting low risk of genotoxicity (threshold of toxicological concern, TTC) [38]. Following the TTC, the amount of genotoxic substances per blood unit should be at maximum 1.5 $\mu \mathrm{g}$. This extrapolates the tolerable total amount to $15 \mu \mathrm{g}$ (if blood products containing up to $250 \mathrm{ml}$ plasma of a single donor are intended) or 75 $\mu \mathrm{g}$ (for blood products with a maximum content of $50 \mathrm{ml}$ single-donor plasma $)$ in whole plasma of the blood donor $(2,500 \mathrm{ml})$. To transfer this value into resulting deferral periods, drug doses must be taken into account as explained in the following example:

Depending on diagnosis, doses of up to $8,000 \mathrm{mg} / \mathrm{m}^{2}$ body surface of the alkylating drug ifosfamide are applied daily to a patient, resulting in $16,000 \mathrm{mg}$ ifosfamide for an adult of $1.8 \mathrm{~m}$ height and $80 \mathrm{~kg}$ body weight with $2 \mathrm{~m}^{2}$ body surface, which is about 1.07 million times $15 \mu \mathrm{g}[39,40]$. A deferral time of $t_{\max }+20 t_{1 / 2}$ leads to $15.3 \mu \mathrm{g}$ ifosfamide in the donor's body. As most drugs for treatment of cancer are definitively genotoxic and bioavailability through blood transfusion is $100 \%$, we propose a deferral period of $t_{\max }+24 t_{1 / 2}$, resulting in about $1 \mu \mathrm{g}$ ifosfamide in the donor. This introduces an additional safety factor of 15 . Most genotoxic drugs are used in much lower doses and usually substantial amounts of the agent are distributed to body compartments outside of the donor's plasma so that the resulting risk should be acceptable even if the genotoxic drugs accumulate in the donor's body [41]. In contrast, drugs showing genotoxic potential in preclinical tests only without clinical evidence of harm in humans are considered to be safe at concentrations of $3 \%$ after transfusion. Literature on them should be monitored permanently.

\section{Class 3 Drugs}

Class 3 drugs requiring no deferral interval include:

\section{Poorly Absorbed Drugs}

Some drugs, e.g. colestipol, nystatin or pyrantel, do not show important systemic effects. Due to their structure, properties or routes of administration, they are only poorly absorbed and in consequence are not present in plasma.

\section{Replacement of Physiological Metabolites}

Vitamins, enzymes, and hormonal preparations for replacement or contraception are also considered to be safe without deferral periods because 
they normally do not exceed the endogenous levels of corresponding compounds or do not cause adverse effects. As an exception, high doses of vitamin A must be considered as a class 1 drug, because of the potency to cause birth defects. For reasons of contraceptive safety for the donor after admission of low-dose gestagens, plasmapheresis must be delayed for up to at least $3 \mathrm{~h}$ after medication, following the guideline of the German authority Paul-Ehrlich-Institute [10].

\section{OTC Drugs and Herbal Drugs}

Although numerous drugs (e.g. herbal drugs) and nutrients are available as 'over-the-counter drugs' (OTC drugs) without prescription, some of them exhibit quite strong effects and interactions, like St. John's Wort [42]. Therefore, their pharmacodynamics and therapeutic index should be taken into account in an individual assessment, whether or not they are in fact class 3 or belong to class 1 or class 2 .

\section{Class 4 Drugs}

Some drugs inhibit platelet aggregation, e.g. the non-steroidal antiinflammatory drugs (NSAID). Therefore, special care is advisable if production of platelet products is intended. Most of these drugs show a dose-dependent reversible inhibition of platelet aggregation, so the influence ends with the elimination of the drug. Waiting periods of $t_{\max }+5 t_{1 / 2}$ as for class 1 drugs are sufficient.

A small number of drugs inactivate platelets irreversibly, like aspirin, clopidogrel, and ticlopidine. Their effects do not end with their elimination. Therefore, normalization of hemostasis is due to production of new platelets. While some regulative authorities recommend deferral of 5 days only for aspirin and clopidogrel and 14 days for ticlopidine, we suggest a deferral period of 10 days for all of them, because the lifetime of human platelets is approximately 10 days (7-14 days) with $10 \%$ of circulating platelets being replaced daily $[12,14,17,43,44]$. Although the terminal plasma elimination half-life of ticlopidine is about $50 \mathrm{~h}$, platelet function returns to normal values within 10 days after the last dose, and surgery is allowed [45].

Inhibition of platelet aggregation is also reported for the selective serotonin reuptake inhibitors (SSRIs), probably via a blockade of serotonin reuptake in platelets $[46,47]$. Calculation of $t_{\max }+5 t_{1 / 2}$ results in deferral periods of several days (e.g. citalopram 8 days, paroxetine 5.5 days, sertraline 6 days, fluvoxamine 5 days, and fluoxetine 7 weeks, approximately) [48-52]; this appears to be sufficient as evidence for an irreversible mechanism of inhibition is missing and literature reports only a small number of bleeding complications.

\section{Results and Recommendations}

Our proposal for eligibility of blood donors on medication is as follows:

\section{Class 1 Drugs}

a) Donors on medication with class 1 drugs should be admitted for blood products containing up to $50 \mathrm{ml}$ single-donor plasma for application to adults.

b) Donors on medication with class 1 drugs intended for blood products to be used in newborns or children $<12$ years or for products containing more than $50 \mathrm{ml}$ single-donor plasma should be admitted for blood donation after a medication-free interval of $t_{\max }+5 t_{1 / 2}$ only.

c) Teratogenic, fetotoxic, or embryotoxic drugs do not require special treatment, a) and b) are valid. However, for the most potent human teratogens, the retinoids, thalidomide, and its analogue lenalidomide as well as for dutasteride and finas- teride, a $t_{\max }+5 t_{1 / 2}$ deferral interval should be applied for any blood product as long as there is no other deferral time required in the product information or by an authority.

\section{Class 2 Drugs}

Treatment of the donor with drugs with genotoxic potential requires a deferral interval of $t_{\max }+24 t_{1 / 2}$ for all blood products or general exclusion from donation because of the underlying disease.

\section{Class 3 Drugs}

Class 3 drugs do not require any deferral period.

\section{Class 4 Drugs}

Medication with irreversible inhibitors of platelet aggregation (acetylsalicylic acid, clopidogrel, ticlopidine) requires deferral for 10 days if production of platelet concentrates is intended, while for reversible inhibitors of platelet aggregation a deferral period of $t_{\max }+5 t_{1 / 2}$ is sufficient. This is also valid for plasma-poor platelet concentrates suspended in additive solution instead of plasma. If production of other blood products is intended, class 4 drugs have to be considered as class 1 drugs.

The above considerations of class 1 to class 4 drugs are also valid if whole blood is donated for fractionation and further processing to different products. The content of single-donor plasma in the final product is the relevant criterion in deciding whether deferral is necessary or not.

\section{Practical Approach at the Blood Bank of the Bavarian Red Cross}

An algorithm for simplifying the determination of deferral periods for blood donors on medication with respect to different blood products is shown in figure 1. Furthermore, calculations according to the above shown principles have been performed for the most common drugs and compiled both in a list and an electronic database. This allows to search for international nonproprietary names (INN) as well as for trade names. Different drug preparations and routes of application were taken into consideration when a special drug release, absorption, or systemic availability is relevant for deferral periods. All drug products have been calculated individually. Generally, the pharmacokinetic data derived from product information and longest $\mathrm{t}_{\max }$ and half-lives reported were used for calculations. When active metabolites of the substances are formed, deferral periods were calculated both for drug and active metabolites and the longer periods were used. In the case of drug combinations, deferral periods were calculated with respect to the drug with the longest elimination time (for examples see table 1). If a drug is not listed, donors are acceptable only if genotoxic substances (class 2 drugs) or retinoids, thalidomide, lenalidomide, dutasteride, or finasteride are not present and $\mathrm{RBCC}$ or PP (up to $50 \mathrm{ml}$ single-donor plasma) for the use in adults are intended. In this way, the responsible physician can decide easily which donor can give blood for which purpose. 
Fig. 1. Algorithm for assessment of eligibility of donors on medication.

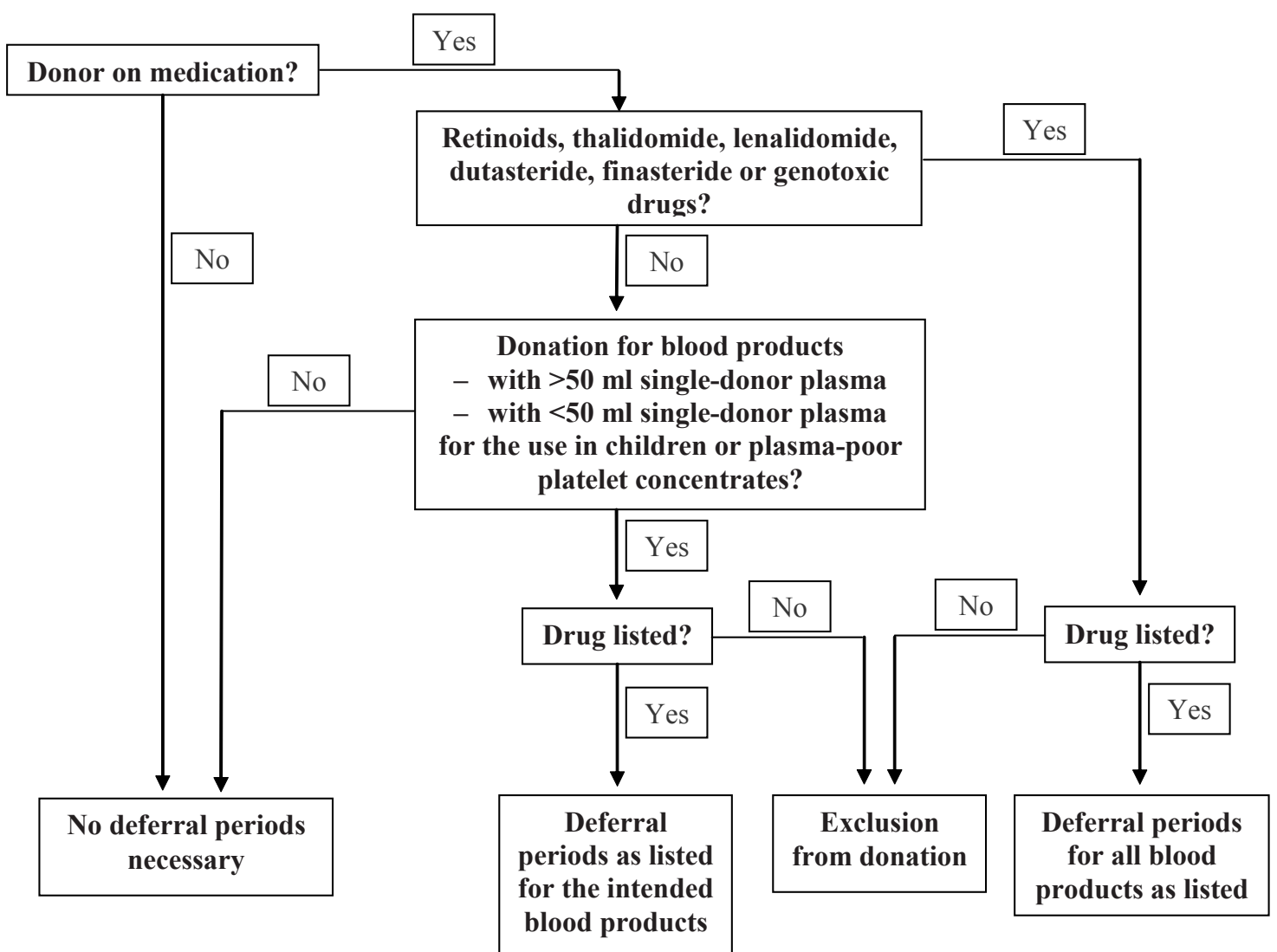

Table 1. Extract of the list of deferral periods

\begin{tabular}{|c|c|c|c|c|}
\hline $\begin{array}{l}\text { Trade name }{ }^{\mathrm{a}} / \\
\text { INN drug name }\end{array}$ & INN drug name & ATC code ${ }^{c}$ & Deferral periods ${ }^{\mathrm{d}}$ & Remarks $^{\mathrm{e}}$ \\
\hline Acarbose & & A 10: drugs used in diabetics & $\begin{array}{l}\text { no deferral period for all blood } \\
\text { products }\end{array}$ & $\begin{array}{l}\text { underlying disease } \\
\text { reason for exclusion? }\end{array}$ \\
\hline Accupro $^{\circledR}$ & quinapril & $\begin{array}{l}\mathrm{C} 09 \text { : agents acting on the renin- } \\
\text { angiotensin system }\end{array}$ & $\begin{array}{l}18 \text { h WB, FFP, PC, children RBCC; } \\
\text { no RBCC adult, PP }\end{array}$ & $\begin{array}{l}\text { underlying disease } \\
\text { reason for exclusion? }\end{array}$ \\
\hline Accuzide $^{\circledR}$ & $\begin{array}{l}\text { quinapril + hydro } \\
\text { chlorothiazide }\end{array}$ & $\begin{array}{l}\mathrm{C} \text { 09: agents acting on the renin- } \\
\text { angiotensin system }\end{array}$ & $\begin{array}{l}45 \text { h WB, FFP, PC, children RBCC; } \\
\text { no RBCC adult, PP }\end{array}$ & $\begin{array}{l}\text { underlying disease } \\
\text { reason for exclusion? } \\
\text { blood pressure? }\end{array}$ \\
\hline $\begin{array}{l}\text { Acetylsalicylic } \\
\text { acid }\end{array}$ & & $\begin{array}{l}\text { B 01: antithrombotic agents; } \\
\text { M 01: antiinflammatory and } \\
\text { antirheumatic products; } \\
\text { N 02: analgesics }\end{array}$ & $\begin{array}{l}3 \text { days WB, FFP, children RBCC; } \\
10 \text { days PC; no RBCC adult, PP }\end{array}$ & $\begin{array}{l}\text { underlying disease } \\
\text { reason for exclusion? } \\
\text { inactivating platelet } \\
\text { function }\end{array}$ \\
\hline Aciclovir & & $\begin{array}{l}\text { D 06: antibiotics and chemo- } \\
\text { therapeutics for dermatological use; } \\
\text { J 05: antivirals for systemic use; } \\
\text { S 01: ophthalmologicals }\end{array}$ & $\begin{array}{l}\text { local: } \text { no deferral period for all } \\
\text { preparations; systemic: } \\
16 \text { h WB, FFP, PC, children RBCC; } \\
\text { no RBCC adult, PP }\end{array}$ & $\begin{array}{l}\text { underlying disease/ } \\
\text { infection reason for } \\
\text { exclusion? }\end{array}$ \\
\hline Acitretin & & D 05: antipsoriatics & 1 year for all blood products & teratogenic \\
\hline Quinapril & & $\begin{array}{l}\mathrm{C} 09 \text { : agents acting on the renin- } \\
\text { angiotensin system }\end{array}$ & $\begin{array}{l}18 \text { h WB, FFP, PC, children RBCC; } \\
\text { no RBCC adult, PP }\end{array}$ & $\begin{array}{l}\text { underlying disease } \\
\text { reason for exclusion? }\end{array}$ \\
\hline
\end{tabular}

RBCC adult $=$ Red blood cell concentrate for adults .

${ }^{a}$ The above mentioned trade names are examples to illustrate the principals of the concept and do not recommend any company.

${ }^{b}$ Trade names and INN drug names in alphabetical order; the accompanying INN drug names of the products are listed in column 2.

'Therapeutic subgroups according to the Anatomical Therapeutic Chemical Classification (ATC) [57].

${ }^{\mathrm{d}}$ Calculated deferral periods for different routes of administration and the different blood products.

${ }^{\mathrm{e}}$ Additional information or links on underlying diseases. 


\section{Discussion}

Our detailed concept is aimed at providing blood banks with a tool to comply with European guidelines on blood donation while minimizing deferral of donors. Use of drugs is widespread among potential blood donors, and due to progressive aging of the population it is to be expected that the number of blood donors on medication will rise [11, 53-56]. Many of them are on long-term treatment. Their exclusion would decrease the availability of donors dramatically. Following our concept, all donors on medication (except for retinoids, thalidomide, lenalidomide, dutasteride, finasteride, or genotoxic/cytostatic drugs) may be accepted if blood banks separate donor blood for distinct purposes, i.e. newborns and children $<12$ years only.

Our concept has some limitations. One of the basic assumptions is that the safe concentration of a drug (without special risks) for the recipient is $3 \%$ of its maximum therapeutic level. This is achieved by deferral periods or dilution of the plasma content in the recipient by transfusion. The real concentration in the donors' plasma depends on the incorporated dose. If a donor is treated with higher doses than normal, higher drug levels will result. Furthermore, excretion rates in donors can differ depending on genetic predisposition or diseases of the excretory organs, which can result in longer half-lives and consequently higher drug levels at the time of donation. Also, transfusion of more than 1 unit of a blood product from the same donor or pooling of blood of donors on the same medication could result in drug concentrations in the recipient's plasma higher than $3 \%$ of the therapeutic concentration in the donors' plasma. However, this scenario appears unlikely because of scattering of blood products on processing, storage, and distribution as well as limited donation frequency. To provide safety, we have used the highest values for a nonpathologic $t_{\max }$ and $t_{1 / 2}$ reported in the literature. In addition, our calculations do not include further reduction of the drug level in the recipient's plasma by distribution into other compartments or degradation of the drug during storage of the blood products.

Red blood cells can contain drugs as well as plasma, either in the cytosol or bound to the surface proteins. Normally, binding and penetration are reversible processes. Thereby, after transfusion of a whole blood unit or RBCC, redistribution into the plasma of the recipient will occur. However, this should not result in a substantial increase of the drug level in plasma because these drugs, if they are able to leave the donors' erythrocytes, will bind again to the erythrocytes of the recipient or penetrate into them [16]. Furthermore, plasma half-live determinations consider redistribution phenomena and thereby are included in our calculations.

A fundamental problem in preventing risks from drugs in blood products is the incomplete anamnesis of donors' present and earlier medications. Intentionally or unintentionally, donors may withhold such information. Several studies reported drugs in donor blood without declaration of medication in the questionnaire, the frequency being between 6 and $11 \%[1-5,11]$. According to our experience, this may partly be due to the donors' knowledge of deferral criteria combined with a strong motivation for donating blood. Our proposal is not to defer donors on medication in general but to decide instead for which recipient the product would be appropriate. We therefore expect that our concept will lead to more precise and complete information provided by donors, resulting in safer blood products. Application of this concept also supports blood donors and their physicians in searching for alternative long-term medications without the need for donor deferral. However, medication should not be stopped because of an intended blood donation.

Our aim was the protection of the recipient from adverse effects by drugs in blood products. Additionally, this may also increase safety for the donor. Especially in the case of plasmapheresis, appropriate abstinence periods from donation will help to prevent unintentional reduction of plasma drug levels necessary for an effective treatment of the donor [10].

\section{General Comments}

Our concept is aimed at risks posed by drugs in blood products only. Therefore, it should be embedded into a quality management system considering all other requirements and regulations for blood donation.

\section{Conclusion}

The presented concept was developed to provide blood banks with a tool to comply with European guidelines on blood donation while minimizing deferral of donors. It has been designed to support blood banks in coming to a decision whether a blood donor on medication has to be rejected or not. Following this, patients on medication are allowed to donate blood for the preparation of blood products containing less than $50 \mathrm{ml}$ plasma volume of a single donor, like RBCC, for the use in adults without deferral periods, except those taking genotoxic drugs, retinoids, thalidomide, lenalidomide, dutasteride, or finasteride. Therefore, even long-term drug therapy is not a criterion for general exclusion from blood donation.

\section{Acknowledgement}

The authors wish to express their special thank to Beate Ulbrich, Federal Institute for Risk Assessment (Berlin, Germany), who gave expert opinion on risk assessment of teratogenic drugs in blood donation. Furthermore, we thank Sonja Mayer, Petra Vogt, and Dorothea Strobach for checking the calculated deferral periods, Saskia Eckert and Sascha Gonder for examination of the comprehensibility of the article, and Kai Dilper for programming the electronic database.

\section{Disclosure}

The authors declared no conflict of interest. 


\section{References}

1 Sharon R, Kidroni G, Michel J: Presence of aspirin in blood units. Vox Sang 1980;38:284-287.

2 Sharon R, Frutkoff I, Kidroni G, Menczel J: Applicability and significance of salicylate screening in sera of voluntary blood donors: evaluation of two analytical methods. J Clin Pathol 1982;35:59-62.

3 Sharon R, Menczel J, Kidroni G: Incidence of acetaminophen in donated blood. Vox Sang 1982;43: 138-141.

4 MacIntyre A, Gray JD, Gorelick M, Renton K: Salicylate and aminophen in donated blood. CMAJ 1986;135:215-216.

5 Mahnovski V, Cheng M, Lipsey A, Keyomarsi K: Drugs in blood donors. Clin Chem 1987;33:189.

6 Fein BT: Aspirin shock associated with asthma and nasal polyps: Ann Allergy 1971;29:598-601.

$>7$ Ferner RE, Dunstan JA, Chaplin S, Baird GM: Drugs in donated blood. Lancet 1989;2:93-94.

8 Stichtenoth DO, Deicher RG, Frölich JC: Blood donors on medication. Eur J Clin Pharmacol 2001;57: 433-440.

9 The Commission of the European Union: Commission Directive 2004/33/EC of 22 March 2004 implementing Directive 2002/98/EC of the European Parliament and of the Council as regards certain technical requirements for blood and blood components. 2004.

10 Paul-Ehrlich-Institut und Wissenschaftlicher Beirat der Bundesärztekammer: Richtlinien zur Gewinnung von Blut und Blutbestandteilen und zur Anwendung von Blutprodukten (Hämotherapie). Bundesanzeiger 2005;209a.

11 Melanson SEF, Stowell CP, Flood JG, Lewandrowski EL, Zak RJ, Lewandrowski KB: Does blood donor history accurately reflect the use of prescription medications? A comparison of donor history and serum toxicologic analysis. Transfusion 2006;46:1402-1407

12 U.S. Department of Health and Human Services, Food and Drug Administration, Center for Biologics Evaluations and Research: Guidance for Industry and FDA Review Staff - Collection of Platelets by Automated Methods. Draft Guidance 2005. www.fda.gov/cber/gdlns/plateletauto.htm

13 AABB - American Association of Blood Banks: Donor History Questionnaire version 1.2 - Medication Deferral List. February 2007. www.aabb. org/Documents/Donate_Blood/Donor_History Questionnaire/udhqmeddefv1-2.pdf

14 UK Blood Transfusion and Tissue Transplantation Services: Whole Blood and Apheresis Donor Selection Guidelines. 2006. www.transfusionguidelines.org.uk/index.asp? Publication $=W B$

15 Blutspendedienst des Bayerischen Roten Kreuzes: Herstellungsanweisung. Version 11, 2003.

16 Derendorf H, Gramatte T, Schäfer HG: Pharmakokinetik - Einführung in die Theorie und Relevanz für die Arzneimitteltherapie, ed. 2, revised. Stuttgart, WVG, 2002.

17 Mutschler E, Geisslinger G, Kroemer HK, Schäfer-Korting M: Arzneimittelwirkungen - Lehrbuch der Pharmakologie und Toxikologie, ed. 8, revised. Stuttgart, WVG, 2001.

18 Buxton ILO: Pharmcokinetics and pharmacodynamics: the dynamics of drug absorption, distribution, action, and elimination; in Brunton L, Lazo J, Parker K (eds): Goodman and Gilman's The Pharmacological Basis of Therapeutics. New York, McGraw-Hill, 2006, pp. 1-40.
19 Fichtl B: Arzneistoffkonzentration im Organismus in Abhängigkeit von der Zeit: Pharmakokinetik im engeren Sinne; in Aktories K, Förstermann U, Hofmann F, Starke K (eds): Allgemeine und spezielle Pharmakologie und Toxikologie. Munich, Urban and Fischer, 2005, pp. 64-81.

20 Menth-Meier, SE, Imoberdorf R, Regli B, Kipfer B, Turgay M, Ballmer PE: Determination of plasma volume by indocyanine green - validation of the method and use in patients after cardiopulmonary bypass. Intensive Care Med 2001;27:925-929.

21 Retzlaff JA, Tauxe WN, Kiely JM, Stroebel CF: Erythrocyte volume, plasma volume, and lean body mass in adult men and women. Blood 1969;33:649667.

22 Rodeck H, Röttger H: Plasmavolumen und extracelluläres Gewebswasser im Laufe der Entwicklung des Kindes. Zeitschrift für Kinderheilkunde 1954;74:610-619.

23 Werner B, Bodin L: Growth from birth to age 19 for children in Sweden born in 1981: descriptive values. Acta Paediartica 2006;95:600-613.

24 Schaefer C, Peters PWJ, Miller R: Drugs during Pregnancy and Lactation. Treatment Options and Risk Assessment. New York, Elsevier/Academic Press, 2007.

25 Schaefer C, Hannemann D, Meister R, Elèfant E, Paulus W, Vial T, Reuvers M, Robert-Gnansia E, Arnon J, De santis M, Clementis M, RodriguezPinilla, Dolivo A, Merlob P: Vitamin K antagonists and pregnancy outcome. A multi-centre prospective study. Thromb Haemost 2006;95:949-957.

26 Schardein JL: Chemically Induced Birth Defects. New York, Marcel Dekker, 2000.

27 Product Information Roaccutan ${ }^{\circledR}$, Roche, German version, June 2006

28 Nulman I, Berkovitch M, Klein J, Pastuszak A, Lester R, Shear N, Koren G: Steady-state pharmacokinetics of isotretionoin and its 4-oxo metabolite: implications for fetal saftey. J Clin Pharmacol 1998;38:926-930.

29 Product Information Neotigason $®$, Roche, German version, January 2007.

30 Etretinate - complete monograph; in Martindale (database on CD-ROM). Updated quarterly. Englewood, CO, Micromedex Inc., vol. 131, 2007.

31 Finasteride - complete monograph; in Martindale (database on CD-ROM). Updated quarterly. Englewood, CO, Micromedex Inc., vol. 131, 2007.

32 Dutasteride - complete monograph; in Martindale (database on CD-ROM). Updated quarterly. Englewood, CO, Micromedex Inc., vol. 131, 2007.

33 Prahalada S, Tarantal AF, Harris GS, Ellsworth KP, Clarke AP, Skiles GL, MacKenzie KI, Kruk LF, Ablin DS, Cukierski MA, Peter CP, vanZwieten MJ, Hendrickx AG: Effects of finasteride, a type 2 5-alpha reductase inhibitor, on fetal development in the rhesus monkey (macaca mulatta). Teratology 1997;55:119-131.

34 Product Information Avodart ${ }^{\circledR}$, Glaxo Smithkline, German version, February 2008

35 Product Information Proscar®, MSD, German version, November 2007.

36 Product Information Propecia ${ }^{\circledR}$, MSD, German version, March 2008.

37 McClellan K, Markham A: Finasteride - a review of its use in male pattern hair loss. Drugs 1999;57: 111-126.
38 The European Medicines Agency (EMEA), Committee for Medicinal Products for Human Use (CHMP): Guideline on the Limits of Genotoxic Impurities. January 2007. www.emea.europa. eu/pdfs/human/swp/519902en.pdf

39 Product Information Holoxan ${ }^{\circledR}$, Baxter, German version, November 2005.

40 Dubois D, Dubois EF: A formula to estimate the approximate surface area if height and weight be known. Arch Intern Med 1916;17:863-871.

41 Seeber S, Schütte J: Therapiekonzepte Onkologie. Berlin, Springer, 2003.

42 St. John's wort - complete monograph; in Martindale (database on CD-ROM). Updated quarterly. Englewood, CO, Micromedex Inc., vol. 131, 2007.

43 Ahrens I, Schwarz M, Peter K, Bode C: Therapeutic inhibitors of platelet aggregation - from Aspirin to integrin blockers. Transfus Med Hemother 2007;34:44-54.

44 Patrono C, Coller B, Dalen JE, FitzGerald GA, Fuster V, Gent M, Hirsh J, Roth G: Platelet-active drugs. The relationships among dose, effectiveness, and side effects. Chest 2001;119(suppl 1):39-63.

45 Product Information Tiklyd ${ }^{\circledR}$, Sanofi Aventis, German version, January 2008.

46 Serebruany VL: Selective serotonin reuptake inhibitors and increased bleeding risk: are we missing something? Am J Med 2006;119:113-116.

47 Yuan Y, Tsoi K, Hunt R: Selective serotonin reuptake inhibitors and risk of upper GI bleeding: confusion or confunding? Am J Med 2006;119:719727.

48 Product Information Cipramil ${ }^{\circledR}$, Lundbeck, German version, March 2008.

49 Product Information Seroxat ${ }^{\circledR}$, Glaxo Smithkline, German version, March 2008.

50 Product Information Zoloft ${ }^{\circledR}$, Pfizer, German version, July 2007.

51 Product Information Fevarin ${ }^{\circledR}$, Solvay, German version, February 2008.

52 Product Information Fluctin ${ }^{\circledR}$, Lilly, German version, September 2008.

53 Bundesvereinigung Dt. Apothekerverbände (ABDA): Publikationen - Figures, Data, Facts - prescribed drugs. www.abda-online.org/zdfo. html $? d b=1$ and and $C M D=$ Detail and ZDFID = 89 and AktivReiter $=3$

54 Bjerrum L, Andersen M, Petersen G, Kragstrup J: Exposure to potential drug interactions in primary health care. Scand J Prim Health Care 2003;21:153158.

55 U.S. Department of Health and Human Services, Centers for Disease Control and Prevention, National Center for Health Statistics: www.cdc.gov/ nchs/data/hus/hus05.pdf\#091

56 Farrales FB, Stevenson AR, Bayer WL: Causes of disqualification in a volunteer blood donor population. Transfusion 1977;17:598-601.

57 WHO Collaborating Centre for Drug Statistics Methodology: ATC/DDD Index 2008. www.whocc. no/atcddd/ 